(2) Open Access Full Text Article

\title{
Omega-3 fatty acid supplementation improves dry eye symptoms in patients with glaucoma: results of a prospective multicenter study
}

This article was published in the following Dove Press journal:

Clinical Ophthalmology

18 May 2016

Number of times this article has been viewed

\author{
Abdullah Kaya' \\ Yakup Aksoy ${ }^{2}$ \\ 'Department of Ophthalmology, \\ Anıttepe Military Dispensary, \\ Ankara, Turkey; ${ }^{2}$ Department of \\ Ophthalmology, Girne Military \\ Hospital, Girne, Cyprus
}

\section{Dear editor}

We read the article entitled "Omega-3 fatty acid supplementation improves dry eye symptoms in patients with glaucoma: results of a prospective multicenter study" by Tellez-Vazquez, with great interest. ${ }^{1}$ The authors found omega-3 fatty acid supplementation to have very beneficial effects on symptoms and clinical findings of dry eye. We appreciate the authors' well-organized study that contained a large number of participants.

Findings in this study show the importance of diet in dry eye syndrome. As a result of industrialization, natural eating habits have changed. Refined foods make up a large part of the diet. Thus, deficiency of essential molecules such as omega-3 is unavoidable. Elderly people especially, may have more deficiency because of potential absorption problems. Omega-3 is important for cell membrane stabilization and health of neural cells. ${ }^{2}$ Deficiency of omega-3 may have a significant role in dry eye, more than estimated. We suggest that supplementation of omega-3 should be recommended to chronic dry eye patients.

\section{Disclosure}

The authors report no conflicts of interest in this communication.

\section{References}

1. Tellez-Vazquez J. Omega-3 fatty acid supplementation improves dry eye symptoms in patients with glaucoma: results of a prospective multicenter study. Clin Ophthalmol. 2016;10:617-626.

2. Bhargava R, Kumar P, Phogat H, Kaur A, Kumar M. Oral omega-3 fatty acids treatment in computer vision syndrome related dry eye. Cont Lens Anterior Eye. 2015;38(3):206-210.
Correspondence: Abdullah Kaya Department of Ophthalmology, Anıttepe Military Dispensary, Yucetepe Mah Gençlik Cad 88 Sok Çankaya/Ankara 6400, Turkey

Tel +90 3/2 $456287 \mid$

Email abdullahkayamd@gmail.com submit your manuscript Dovepress
Clinical Ophthalmology 2016:10 9/1-9/2 and incorporate the Creative Commons Attribution - Non Commercial (unported, v3.0) License (http://creativecommons.org/licenses/by-nc/3.0/). By accessing the work you hereby accept the Terms. Non-commercial uses of the work are permitted without any further permission from Dove Medical Press Limited, provided the work is properly attributed. For permission for commercial use of this work, please see paragraphs 4.2 and 5 of our Terms (https://www.dovepress.com/terms.php). 


\section{Author's reply}

Jesús Tellez-Vazquez

On behalf of the Dry Eye In Glaucoma Study Group (DEIGSG)

Glaucoma Section, Ophthalmology Department, Hospital de la Santa Creu i Sant Pau, Barcelona, Spain

Correspondence: Jesús Tellez-Vazquez

Glaucoma Section, Ophthalmology Department, Hospital de la Santa Creu i Sant Pau, C/Sant Antoni M Claret I67, E-08025 Barcelona, Spain Tel +34932919000

Email jesustellez22@yahoo.es

\section{Dear editor}

We appreciate very much the supportive and appreciative comments of Drs Kaya and Aksoy regarding the benefits of dietary supplementation with polyunsaturated fatty acids (PUFAs) for improving dry eye symptoms, in this particular case, in patients with glaucoma using topical antihypertensive drugs. Based on a number of clinical studies on the same topic previously published in the literature, there is sufficient evidence for insistently recommending supplementation with omega-3 PUFA in patients with chronic dry eye symptoms, mainly in those not fully satisfied with the use of artificial tears free of conservatives. In intervention trials, both openlabel studies with a large population of patients with dry eye symptoms, ${ }^{1}$ and in controlled trials with smaller samples of patients presenting with dry eye syndrome either due to refractive surgery ${ }^{2}$ or other causes, ${ }^{3,4}$ as well as in patients with primary open-angle glaucoma ${ }^{5}$ suffering from dry eye symptoms related to the chronic use of topical antiglaucoma medications, statistically significant improvements of dry eye signs and symptoms were consistently found in the supplemented group as compared to nonsupplemented patients or healthy controls. Moreover, the expression of cytokine markers in reflex tear samples was also significantly reduced in the supplementation group. These results have also been replicated in a double blind placebo-controlled trial in patients with dry eye symptoms due to meibomian gland dysfunction. ${ }^{6}$ A statistically significant improvement in health-related quality of life ${ }^{7}$ among patients in the supplemented group versus controls was another remarkable finding of the trial. These observations are clinically relevant and have direct practical implications, since oral supplementation with omega-3 fatty acids has been demonstrated to be an effective and advantageous option for the relief of persistent and annoying symptoms of dry eye in a variety of ophthalmological settings.

\section{Disclosure}

The author reports no conflicts of interest in this communication.

\section{References}

1. Oleñik A. Effectiveness and tolerability of dietary supplementation with a combination of omega- 3 polyunsaturated fatty acids and antioxidants in the treatment of dry eye symptoms: results of a prospective study. Clin Ophthalmol. 2014;8:169-176.

2. Ong NH, Purcell TL, Roch-Levecq AC, et al. Epithelial healing and visual outcomes of patients using Omega-3 oral nutritional supplements before and after photorefractive keratectomy: a pilot study. Cornea. 2013;32(6): 761-765.

3. Kangari H, Eftekhari MH, Sardari S, et al. Short-term consumption of oral omega-3 and dry eye syndrome. Ophthalmology. 2013;120(11): 2191-2196.

4. Pinazo-Duran MD, Galbis-Estrada C, Pons-Vazquez S, et al. Effects of a Nutraceutical formulation based on the combination of antioxidants and $\omega-3$ essential fatty acids in the expression of inflammation and immune response mediators in tears from patients with dry eye disorders. Clin Interv Aging. 2013;8:139-148.

5. Galbis-Estrada C, Pinazo-Duran MD, Cantu-Dibildox J, et al. Patients undergoing long-term treatment with antihypertensive eye drops responded positively with respect to their ocular surface disorder to oral supplementation with antioxidants and essential fatty acids. Clin Interv Aging. 2013;8:711-719.

6. Oleñik A, Jiménez-Alfaro I, Alejandre-Alba N, Mahillo-Fernández I. A randomized, double-masked study to evaluate the effect of omega-3 fatty acids supplementation in meibomian gland dysfunction. Clin Interv Aging. 2013;8:1133-1138.

7. Oleñik A, Jiménez-Alfaro I, Alejandre-Alba N, et al. Benefits of omega-3 fatty acid dietary supplementation on health-related quality of life in patients with meibomian gland dysfunction. Clin Ophthalmol. $2014 ; 8: 831-836$

Dove Medical Press encourages responsible, free and frank academic debate. The content of the Clinical Ophthalmology 'letters to the editor' section does not necessarily represent the views of Dove Medical Press, its officers, agents, employees, related entities or the Clinical Ophthalmology editors. While all reasonable steps have been taken to confirm the content of each letter, Dove Medical Press accepts no liability in respect of the content of any letter, nor is it responsible for the content and accuracy of any letter to the editor.

Clinical Ophthalmology

\section{Publish your work in this journal}

Clinical Ophthalmology is an international, peer-reviewed journal covering all subspecialties within ophthalmology. Key topics include: Optometry; Visual science; Pharmacology and drug therapy in eye diseases; Basic Sciences; Primary and Secondary eye care; Patient Safety and Quality of Care Improvements. This journal is indexed on Submit your manuscript here: http://www.dovepress.com/clinical-ophthalmology-journal
Dovepress

PubMed Central and CAS, and is the official journal of The Society of Clinical Ophthalmology (SCO). The manuscript management system is completely online and includes a very quick and fair peer-review system, which is all easy to use. Visit http://www.dovepress.com/ testimonials.php to read real quotes from published authors. 